\title{
Total Synthesis of Lipoteichoic Acid of Streptococcus pneumoniae**
}

\author{
Christian Marcus Pedersen, Ignacio Figueroa-Perez, Buko Lindner, Artur J. Ulmer, \\ Ulrich Zähringer, and Richard R. Schmidt*
}

\author{
Dedicated to Professor Hans Paulsen
}

\begin{abstract}
Streptococcus pneumoniae is one of the most common Grampositive pathogens. Upon colonizing the upper respiratory tract it causes severe infections and it causes life-threatening diseases like pneumonia, bacteremia, and meningitis when it reaches the lower respiratory tract or the bloodstream, ${ }^{[1]}$ thereby resulting in a high mortality rate. ${ }^{[2,3]}$

As for all Gram-positive bacteria, the cell wall of $S$. pneumoniae consists of several layers of peptidoglycans, to which teichoic acids are covalently linked, and of lipoteichoic acids (LTAs) which are anchored in the cell membrane. Structural analysis of pneumococcal LTA revealed quite a different chemical composition compared to that of LTA from Staphylococcus aureus. ${ }^{[4]}$ The polyglycerophosphate backbone of staphylococcal LTA is replaced by a pentameric repeating unit which consists of a ribitolphosphate having in some cases an attached GalNAc residue and a tetrasaccharide moiety connected to two attached phosphocholine residues (Scheme 1, 1). ${ }^{[4,5]}$
\end{abstract}

The pneumococcal LTA is recognized by the innate immune system, thereby stimulating the release of proinflammatory cytokines, but with reduced potency compared to staphylococcal LTA. ${ }^{[6]}$ Activation is supposed to occur through the Toll-like receptor 2 (TLR-2) with CD14 as a coreceptor. ${ }^{[7]}$ However, as TLR-2 appears to recognize a broad range of structurally different bacterial compounds, specific stimulation of the immune system through a TLR-2-LTA interaction has been recently questioned. ${ }^{[8-11]}$ In addition, different strains of Gram-positive bacteria produce LTAs having structural variations. Therefore, pneumococcal LTA may have galactose instead of glucose in the repeating unit, ${ }^{[12]}$ ribitol with D-alanine residues, ${ }^{[13,14]}$ or heterogeneity in the attached phosphocholines. ${ }^{[4]}$ These structural changes may

[*] Dr. C. M. Pedersen, Dr. I. Figueroa-Perez, Prof. Dr. R. R. Schmidt Fachbereich Chemie, Universität Konstanz

Fach 725, 78457 Konstanz (Germany)

Fax: $(+49)$ 7537-883-135

E-mail: richard.schmidt@uni-konstanz.de

Priv.-Doz. Dr. B. Lindner, Prof. Dr. A. J. Ulmer, Prof. Dr. U. Zähringer Forschungszentrum Borstel, Leibniz-Zentrum für Medizin und Biowissenschaften, 23845 Borstel (Germany)

[ㅊ: This work was supported by the Deutsche Forschungsgemeinschaft and the Fonds der Chemischen Industrie. C.M.P. is particularly grateful for a fellowship from the Danish Agency for Science, Technology and Innovation. We wish to thank B. Wegner, H. Moll, H. Käßner, and Dr. N. Gisch for excellent LTA purification and help in MS and NMR analyses. alter LTA-mediated functions of the bacterial cell wall, such as adhesion to host cells, growth, and pathogenicity.

To investigate the impact of LTA and the effect of its structural modifications upon LTA function, we developed the first, and modular, synthesis of streptococcal LTA from the R6 strain. ${ }^{[4,13]}$ Hence, the major structural isomer 1 a, having $\mathrm{R}=\mathrm{H}, \mathrm{X}=\mathrm{NH}_{3}{ }^{+}$, and $n=1$ (instead of about 2), ${ }^{[13]}$ was selected as a target molecule. In this way, the previous structural assignments could also be confirmed.

The design of the synthesis of LTA 1a is outlined in Scheme 1. For a convergent synthesis, disconnections at two glycosidic linkages (1) and (3)) and at the phosphate linkages (2) and (4), were envisaged, which would lead to the A-DAG (DAG = diacylglycerol), CB, ED, and HGF fragments. The disconnections of each of the fragments results in nine carbohydrate-derived building blocks (2-10). Compound 2 is required as a precursor for the DAG moiety and compounds $\mathbf{3 - 1 0}$ are precursors for the sugar moieties $\mathbf{A}-\mathbf{H}$ in the target molecule. The stereoselective generation of the glycosidic linkage will be performed with $O$-glycosyl trichloroacetimidates as glycosyl donors. ${ }^{[15]}$

For the envisaged modular synthesis of structurally heterogeneous streptococcal LTAs, the building blocks for sugar moieties $\mathbf{B}, \mathbf{D}$, and $\mathbf{G}$ are particularly important. The 2acetamino-4-amino-2,4,6-trideoxygalactose $\mathbf{B}$ is frequently found as a constituent of bacterial saccharides ${ }^{[4]}$ derivatives of this compound have been synthesized and also used in the synthesis of fragments related to LTA from $S$. pneumoniae. ${ }^{[16]}$ For the total synthesis of $\mathbf{1 a}, \mathbf{B}$ requires orthogonal N protection, hence the benzyloxycarbonyl protecting group $(\mathrm{Z})$ at the 4-position was chosen to allow the generation of an amino or an acetylamino group, and the Troc group at the 2-position was chosen to facilitate formation of the $\beta$ linkage in the glycosylation step for the glycosyl donor 4 . The donor 4 was obtained from glucosamine by a demanding route (Scheme 2) ${ }^{[17]}$ After the transformation of glucosamine into the 2-azido derivative $\mathbf{1 1}^{[18]}$ and subsequent $\mathrm{O}$-deacetylation, the decisive steps for an efficient synthesis of 4 were the regioselective 6-O-tosylation, which permitted the straightforward generation of the 6-deoxy derivative $\mathbf{1 2}$, and then regioselective 3-O-benzoylation. Subsequently, the 4-O-triflate could be formed and then reacted with potassium phthalimide to deliver the versatile intermediate 13. Replacement of the phthalimido group by the $\mathrm{Z}$ group, reduction of the azide, and then introduction of the Troc group afforded 14, which was readily transformed into the glycosyl donor 4 . The structurally closely related moiety $\mathbf{G}$ also requires orthogonal N protection: a phthalimido group at the 


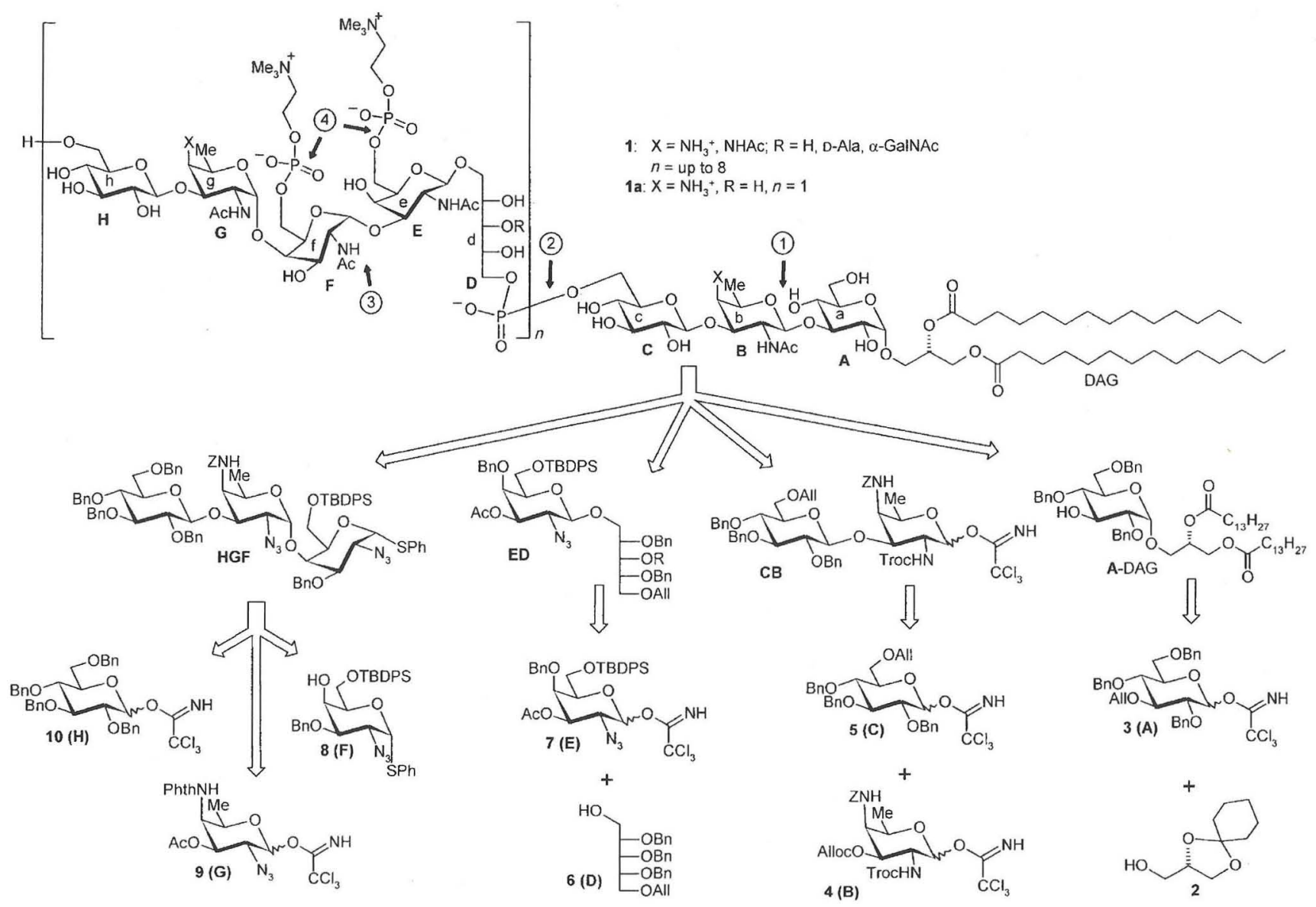

Scheme 1. LTA of Streptococcus pneumoniae and the retrosynthetic strategy showing building blocks $2-10$. All $=$ allyl, Alloc $=$ allyloxycarbonyl, Bn $=$ benzyl, TBDPS $=$ tert-butyldiphenylsilyl, Troc $=2,2,2$-trichloroethoxycarbonyl.

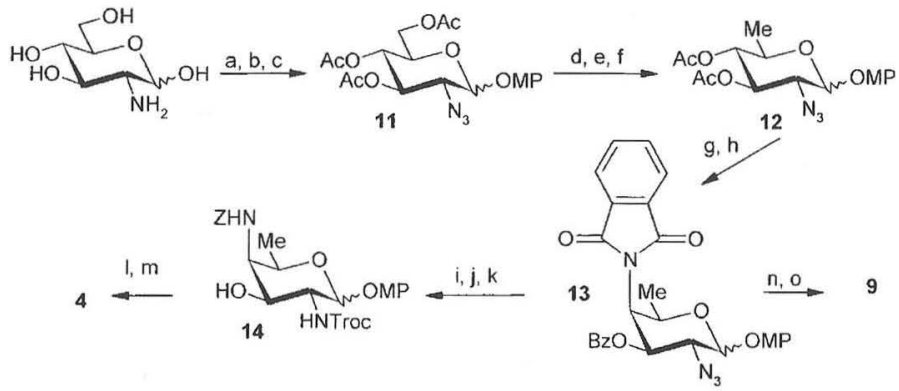

Scheme 2. Synthesis of glycosyl donors 4 and 9 . Reagents and conditions: a) $\mathrm{TfN}_{3}$; b) $\mathrm{Ac}_{2} \mathrm{O}$, Pyr (73\%); c) $4-\mathrm{MeOC}_{6} \mathrm{H}_{4} \mathrm{OH}, \mathrm{TfOH}, \mathrm{CH}_{2} \mathrm{Cl}_{2}, 0^{\circ} \mathrm{C}(84 \%)$; d) 1. $\mathrm{NaOMe}, \mathrm{MeOH}, 2$. TsCl, Pyr, 3. $\mathrm{Ac}_{2} \mathrm{O}$, DMAP (94\%); e) TBAI, MeCN, reflux (98\%); f) $\mathrm{NaBH}_{3} \mathrm{CN}, \mathrm{DMPU}, 95^{\circ} \mathrm{C}(86 \%)$; g) 1. $\mathrm{NaOMe}, \mathrm{MeOH}, 2 . \mathrm{BzCl}, \mathrm{Pyr}$, $-30^{\circ} \mathrm{C}(61 \%)$; h) 1. $\mathrm{Tf}_{2} \mathrm{O}, \mathrm{Pyr}, 2$. PhthNK, DMF, RT (84\%); i) $\left(\mathrm{CH}_{2} \mathrm{NH}_{2}\right)_{2}, \mathrm{BuOH}$ (68\%); j) $\mathrm{ZCl}, \mathrm{NaHCO}_{3}, \mathrm{THF} / \mathrm{H}_{2} \mathrm{O}(4: 1 ; 88 \%)$; k) 1. Raney-Ni, $\mathrm{H}_{2}, \mathrm{EtOH}$, 2. Troc- $\mathrm{Cl}, \mathrm{NaHCO}_{3}(71 \%)$; I) Alloc-Cl, Pyr (85\%); m) 1. CAN, $\mathrm{MeCN} / \mathrm{H}_{2} \mathrm{O}$, 2. $\mathrm{CCl}_{3} \mathrm{CN}, \mathrm{DBU}, \mathrm{CH}_{2} \mathrm{Cl}_{2}(89 \%)$; n) $\mathrm{Phl}\left(\mathrm{O}_{2} \mathrm{C}-\mathrm{CF}_{3}\right)_{2}, \mathrm{BF}_{3} \cdot \mathrm{OEt}_{2}, \mathrm{CH}_{2} \mathrm{Cl}_{2}$ saturated with $\mathrm{H}_{2} \mathrm{O}(87 \%)$; o) $\mathrm{CCl}_{3} \mathrm{CN}, \mathrm{DBU}, \mathrm{CH}_{2} \mathrm{Cl}_{2}(72 \%)$. $\mathrm{Bz}=$ benzoyl, $\mathrm{CAN}=$ ceric ammonium nitrate, $\mathrm{DBU}=1$,8-diazabicyclo[5.4.0] undec-7-ene, $\mathrm{DMAP}=4$-(dimethylamino) pyridine, $\mathrm{DMF}=\mathrm{N}, \mathrm{N}$-dimethylformamide, $\mathrm{DMPU}=\mathrm{N}, \mathrm{N}^{\prime}$-dimethyl$N, N^{\prime}$-propylideneurea, MP =4-methoxyphenyl, $\mathrm{Phth}=$ phthaloyl, $\mathrm{Pyr}=$ pyridine $\mathrm{TBAI}=$ tetra- $n$-butylammonium iodide, $\mathrm{Tf}=$ trifluoromethanesulfonyl,

$\mathrm{THF}=$ tetrahydrofuran, $\mathrm{Ts}=4$-toluenesulfonyl, $\mathrm{Z}=$ benzyloxycarbonyl (instead of $\mathrm{Z}$ also $\mathrm{Cbz}$ is used as an abbreviation). 4-position and a 2-azido group facilitate the $\alpha$ selectivity in the glycosylation step and allow the installation of an amino or an acetylamino group at $\mathrm{C} 4$, thereby leading to the requisite glycosyl donor $\mathbf{9}$. Donor 9 was readily obtained in two steps from intermediate $\mathbf{1 3} .^{[17]}$ For the ribitol residue $\mathbf{D}$, introduction of an $\alpha$-GalNAc residue or eventually a D-alanyl residue at $\mathrm{O} 3$ has to be envisaged. Hence, in addition to the known building block 6 , obtained from D-ribose in six steps, ${ }^{[19]}$ the 3-O-naphthylmethyl-protected derivative, which possesses an oxidatively labile protecting group to permit the required orthogonal protecting group removal, ${ }^{[20]}$ was prepared.

The galactosamine derived sugars $\mathbf{E}$ and $\mathbf{F}$ carrying the phosphocholine residues at $\mathrm{O} 6$ are $\beta-1,3-$ and $\alpha-1,4$-linked, respectively. Therefore, when starting from galactosamine different strategies for the synthesis of building blocks $\mathbf{7}$ and $\mathbf{8}$, requiring permanent benzyl protection at $\mathrm{O} 4$ or at $\mathrm{O} 3$, respectively, were required. Azido groups in the 2-position were chosen for $\mathbf{7}$ and $\mathbf{8}$ (as for $\mathbf{9}$ ) to concomitantly generate the desired acetamino groups. In this way the $\alpha$ linkage required for $\mathbf{7}$ would arise from thermodynamic control, and the $\beta$ linkage required for $\mathbf{8}$ would arise 
from the (kinetic) nitrile effect. ${ }^{[21]}$ Temporary and overall orthogonal TBDPS protection at O6 was chosen for the regioselective introduction of the two phosphocholine residues. Hence, galactosamine was transformed by azidation, ${ }^{[18,22]}$ thioglycoside formation, and 4,6-O-benzylidenation into the valuable intermediate $\mathbf{1 5}$ (Scheme 3). Compound 15

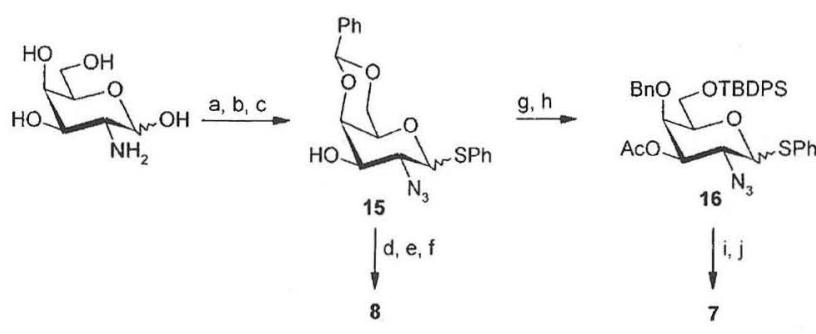

Scheme 3. Synthesis of building blocks 7 and 8. Reagents and conditions: a) 1. $\mathrm{TfN}_{3}, 2 . \mathrm{Ac}_{2} \mathrm{O}$, $\mathrm{Pyr}(77 \%)$; b) $\mathrm{PhSH}, \mathrm{BF}_{3} \cdot \mathrm{OEt}_{2}, \mathrm{CH}_{2} \mathrm{Cl}_{2}$ $(84 \%)$; c) 1. $\mathrm{NaOMe}, \mathrm{MeOH}, 2 . \mathrm{PhCH}(\mathrm{OMe})_{2}, p-\mathrm{TsOH}, 40^{\circ} \mathrm{C}(93 \%)$; d) $\mathrm{BnBr}, \mathrm{NaH}$, DMF (88\%); e) $\mathrm{CSA}, \mathrm{CH}_{2} \mathrm{Cl}_{2} / \mathrm{MeOH}$ (77\%); f) TBDPSCl, Imidazole, DMF (94\%); g) 1. $\mathrm{Ac}_{2} \mathrm{O}, \mathrm{Pyr}, 2 . \mathrm{NaCNBH}_{3}$, $\mathrm{Bu}_{2} \mathrm{BOTf}, \mathrm{CH}_{2} \mathrm{Cl}_{2}$ (74\%); h) TBDPSCl, Imidazole, $\mathrm{CH}_{2} \mathrm{Cl}_{2}$ (92\%); i) $\mathrm{NBS}, \mathrm{Me}_{2} \mathrm{CO},-15^{\circ} \mathrm{C}(86 \%)$; j) $\mathrm{CCl}_{3} \mathrm{CN}, \mathrm{DBU}, \mathrm{CH}_{2} \mathrm{Cl}_{2}(91 \%)$. $\mathrm{NBS}=\mathrm{N}$-bromosuccinimide.

then afforded, after 3-O-benzylation, benzylidene removal, and regioselective 6-O-silylation with TBDPSCl, the desired 4-O-unprotected $\mathbf{8}$ as the acceptor. 3-O-Acetylation of $\mathbf{1 5}$ and then reductive opening of the benzylidene ring furnished the 4-O-benzylated intermediate, which upon 6-O-silylation gave the desired orthogonally protected intermediate 16. This intermediate was readily transformed into the desired donor 7.

As there are no further functional groups attached to glucose residues $\mathbf{A}, \mathbf{C}$, and $\mathbf{H}$, standard chain extending building blocks having one temporary protecting group are required. For temporary protection for $\mathbf{A}$ a 3-O-allyl group was chosen, which resulted in a known glycosyl donor $(3)^{[23]}$ as a precursor, and for $\mathbf{C}$ a 6-O-allyl group was chosen, thereby resulting in the known glycosyl donor $5^{[24]}$ as a precursor. Similarly the anticipated $\alpha$ - and $\beta$ linkage formation would depend upon the thermodynamic anomeric effect and on the nitrile effect, respectively. For chain termination at glucose residue $\mathbf{H}$ the standard tetra-O-benzyl-glucosyl donor $\mathbf{1 0}^{[15]}$ was sufficient as a precursor. For the ligation of more than one repeating unit $(n=2$, etc.) the introduction of phenoxyacetyl at O6 was successfully investigated. 1,2-O-Cyclohexylidene-sn-glycerol (2) is readily obtained from D-mannitol. ${ }^{[25]}$

With these building blocks the total synthesis of target molecule 1 a could be investigated. The A-DAG precursor 17 (Scheme 4) was obtained from 2 and $\mathbf{3}$ in high overall yield and acceptable anomeric selectivity by using TMSOTf as a catalyst in dichloromethane at room temperature. Removal of the cyclohexylidene group and introduction of two myristoyl residues under standard reaction condi- tions afforded, after O-deallylation with palladium chloride in the presence of sodium acetate and acetic acid in ethyl acetate ${ }^{[26]}$ the 3-O-unprotected A-DAG intermediate $\mathbf{1 8}$ as the acceptor. As the anticipated convergent synthesis of the CBA-DAG intermediate caused unexpected problems, ${ }^{[17]}$ this compound was successfully synthesized in a linear fashion. Therefore, the reaction of $\mathbf{1 8}$ with $\mathbf{4}$ as glycosyl donor furnished, as a result of anchimeric assistance, the desired $\beta$ linkage in the resulting disaccharide in high yield. Removal of the Alloc group using $\left[\mathrm{Pd}\left(\mathrm{PPh}_{3}\right)_{4}\right]$ and $p$-toluenesulfinate as the nucleophile ${ }^{[27]}$ afforded the 3b-O-unprotected BA-DAG intermediate 19 as an acceptor. Reaction of $\mathbf{1 9}$ with glycosyl donor 5 was performed under TMSOTf catalysis at $-45^{\circ} \mathrm{C}$ in propionitrile to obtain, with the help of the nitrile effect, ${ }^{[21]}$ mainly the desired $\beta$-linked trisaccharide intermediate. After reaction of the intermediate with $\mathrm{Zn}$ in acetic anhydride, Troc removal and $\mathrm{N}$-acetylation ensued in high yield. ${ }^{[28]} 6 \mathrm{c}-\mathrm{O}-$ Deallylation was performed as described above. Phosphitylation of this compound with bis(diisopropylamino)cyanoethoxyphosphine in the presence of diisopropylammonium tetrazolide $^{[29]}$ afforded the CBA-DAG core structure 20, which was suited for chain extension and hydrogenolysis to readily liberate all functional groups. ${ }^{[17]}$

The HGFED repeating unit 24, a pseudopentasaccharide, was constructed from trisaccharide $\mathbf{2 2}$ as the glycosyl donor and pseudodisaccharide $\mathbf{2 3}$ as the acceptor (Scheme 5). To this end, 4-O-unprotected acceptor $\mathbf{8}$ was glycosylated with donor 9 under TMSOTf catalysis in $\mathrm{CH}_{2} \mathrm{Cl}_{2}$ at room temperature to afford $\alpha$-linked disaccharide $\mathbf{2 1}$ (GF) in high yield. Replacement of the N-phthaloyl group, which was required for high $\alpha$ selectivity in the glycosylation step, by the benzyloxycarbonyl $(\mathrm{Z})$ group was performed by using a

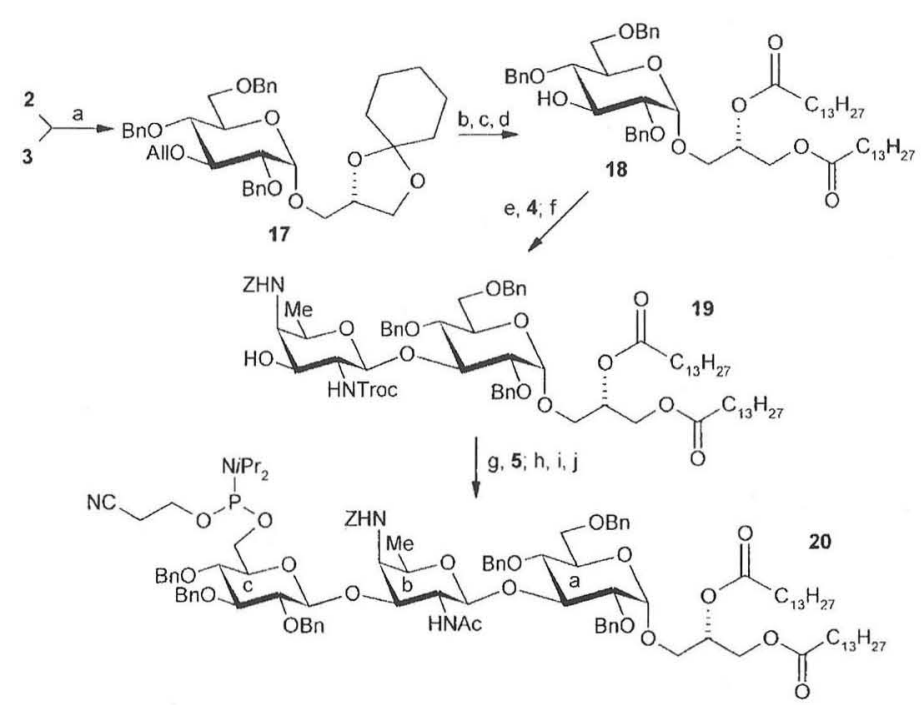

Scheme 4. Synthesis of CBA-DAG intermediate 20. Reagents and conditions: a) TMSOTf (0.05 equiv), $\mathrm{CH}_{2} \mathrm{Cl}_{2}$, RT ( $\left.89 \%, \alpha / \beta=4: 1\right)$; b) $\mathrm{HOAc}, 80^{\circ} \mathrm{C}(87 \%)$; c) $\mathrm{C}_{13} \mathrm{H}_{27} \mathrm{CO}_{2} \mathrm{H}$, DMAP, DCC (75\%); d) $\mathrm{PdCl}_{2}, \mathrm{NaOAc}, \mathrm{HOAc}, \mathrm{EtOAc}(73 \%)$; e) TMSOTf, $\mathrm{CH}_{2} \mathrm{Cl}_{2}$, RT $(93 \%$, only $\beta) ; f$ ) $\left[\mathrm{Pd}\left(\mathrm{PPh}_{3}\right)_{4}\right]$, TolsO $\mathrm{Sa}_{2} \mathrm{Na}, \mathrm{MeOH}, \mathrm{THF}$ (69\%); g) TMSOTf, EtCN, $-45^{\circ} \mathrm{C}(83 \%, \beta / \alpha=5: 1)$; h) $\mathrm{Zn}, \mathrm{Ac}_{2} \mathrm{O}$, ultrasound (86\%); i) $\mathrm{PdCl}_{2}, \mathrm{MeOH}, \mathrm{CH}_{2} \mathrm{Cl}_{2}(79 \%)$; $\left(\mathrm{Pr}_{2} \mathrm{~N}\right)_{2} \mathrm{P}-\mathrm{OCH}_{2} \mathrm{CH}_{2} \mathrm{CN}$, tetrazole, $i \mathrm{Pr}_{2} \mathrm{NH}$ $(86 \%)$. TMS $=$ trimethylsilyl, DCC $=$ dicyclohexylcarbodiimide. 


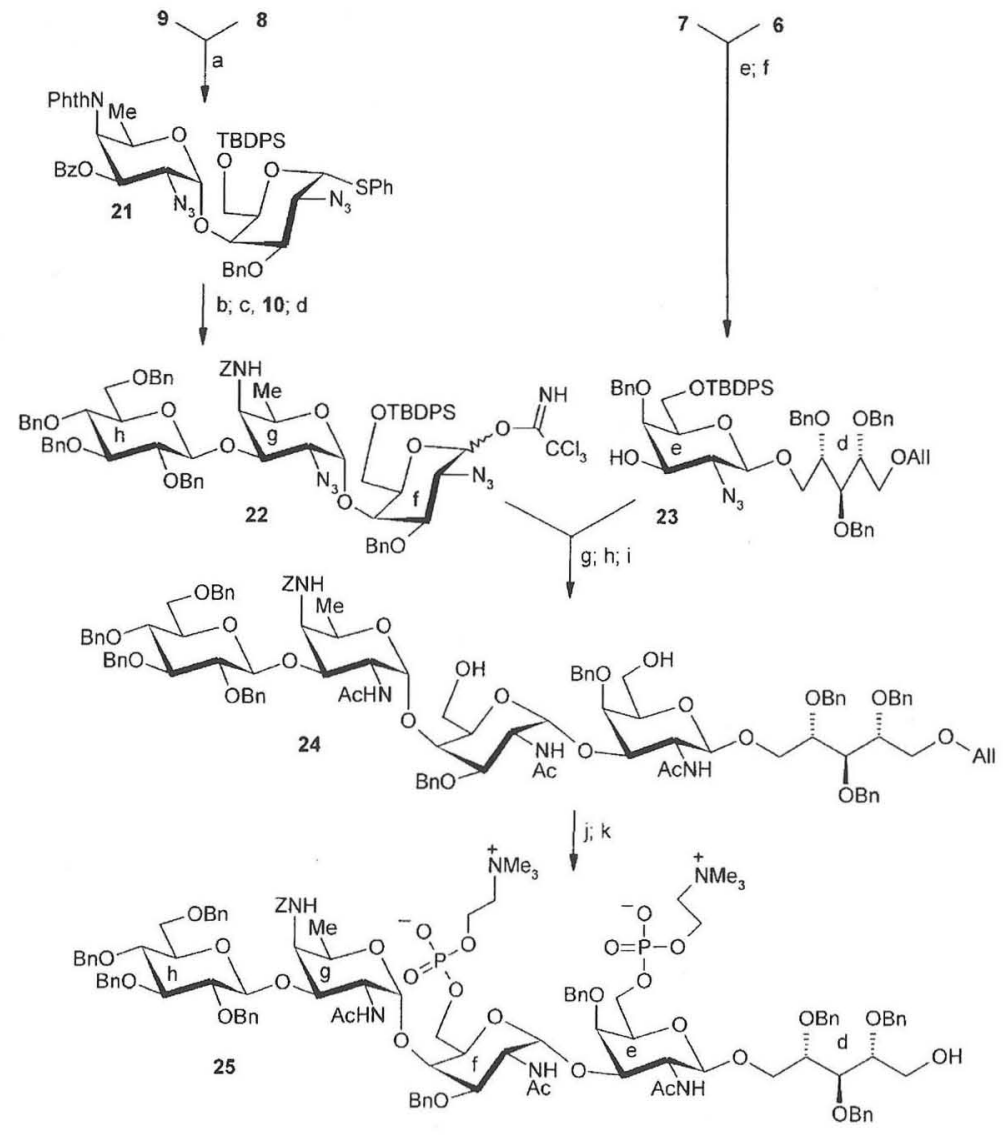

Scheme 5. Synthesis of HGFED intermediate 25. Reagents and conditions: a) TMSOTf (0.1 equiv), $\mathrm{CH}_{2} \mathrm{Cl}_{2}$, RT (76\%); b) $\mathrm{NaOMe}, \mathrm{MeOH}$; then $\mathrm{H}_{2} \mathrm{NCH}_{2} \mathrm{CH}_{2} \mathrm{NH}_{2}, \mathrm{NaOMe}$, $\mathrm{BuOH}$; then $\mathrm{ZCl}, \mathrm{NaHCO}_{3}(92 \%)$; c) TMSOTf ( 0.15 equiv), $\mathrm{MeCN},-40^{\circ} \mathrm{C}(94 \%)$; d) NBS, $\mathrm{Me}_{2} \mathrm{CO}, \mathrm{H}_{2} \mathrm{O},-15^{\circ} \mathrm{C}$; then $\mathrm{CCl}_{3} \mathrm{CN}, \mathrm{DBU}, \mathrm{CH}_{2} \mathrm{Cl}_{2}$ (71\%); e) TMSOTf (0.1 equiv), $\mathrm{MeCN},-40^{\circ} \mathrm{C}$ (88\%); f) NaOMe, $\mathrm{MeOH}$ (quant); g) TMSOTf, $\mathrm{CH}_{2} \mathrm{Cl}_{2}(89 \%)$; h) $\mathrm{H}_{2} \mathrm{~S}$, Pyr, $\mathrm{H}_{2} \mathrm{O}$; then $\mathrm{Ac}_{2} \mathrm{O}$, Pyr (84\%); i) HF, Pyr (91\%); j) $i \mathrm{Pr}_{2} \mathrm{NP}\left(\mathrm{OCH}_{2} \mathrm{CH}_{2} \mathrm{CN}\right)$ $\mathrm{OCH}_{2} \mathrm{CH}_{2} \mathrm{NMe}_{3}{ }^{+} \mathrm{TsO}^{-}$, tetrazole, $\mathrm{MeCN}$; then $t \mathrm{BuO}_{2} \mathrm{H}$ (89\%); $\left.\mathrm{k}\right)\left[\left(\mathrm{Ph}_{3} \mathrm{P}\right)_{2} \mathrm{RuCl}_{2}\right], \mathrm{DBU}$, $\mathrm{EtOH}$; then $\mathrm{HCl}, \mathrm{Me}_{2} \mathrm{CO}(81 \%)$.

method published by Hindsgaul and co-workers, ${ }^{[30]}$ after which the $\mathrm{Z}$ group was introduced. This procedure led to concomitant loss of the $3 \mathrm{~g}$-O-benzoyl group. Glycosylation with the donor $\mathbf{1 0}$, taking again advantage of the nitrile effect, ${ }^{[21]}$ furnished the desired $\beta$ linkage in the HGF trisaccharide in very high yield. The phenylthio group was cleaved with NBS in aqueous acetone affording the desired 1f-Ounprotected intermediate, which was readily transformed into the trichloroacetimidate $\mathbf{2 2}$ as the glycosyl donor. Glycosylation of the ribitol derivative $\mathbf{6}$, having a 3-O-benzyl group, with glycosyl donor $\mathbf{7}$ afforded the $\beta$-linked pseudodisaccharide (ED) in very high yield. This transformation proceeded by taking advantage of the nitrile effect. After 3e-O-deacetylation with sodium methanolate in $\mathrm{MeOH}$ the desired intermediate $\mathbf{2 3}$ was obtained. Glycosylation of acceptor $\mathbf{2 3}$ with the donor 22 using a TMSOTf catalyst in $\mathrm{CH}_{2} \mathrm{Cl}_{2}$ at room temperature furnished the desired $\alpha$ linkage to provide the HGEFD intermediate in high yield. The three azido groups could be concomitantly transformed into acetamino groups by treatment first with hydrogen sulfide in aqueous pyridine and then with acetic anhydride in pyridine. 6e,6f-O-Desilylation with hydrogen fluoride in pyridine afforded the HGFED intermediate 24. The introduction of the phosphocholine residues was performed with cholinoxy-cyanoethoxy-diisopropylaminophosphine ${ }^{[31]}$ using tetrazole as the activator, and then oxidation using tert-butyl hydroperoxide to deliver the desired product in high yield. 1d-O-Deallylation was successfully achieved with the $\left[\left(\mathrm{Ph}_{3} \mathrm{P}\right)_{2} \mathrm{RuCl}_{2}\right]$ complex ${ }^{[32]}$ as the catalyst, thereby leading to double bond migration. Final acid hydrolysis of the resulting enol ether afforded the desired HGFED intermediate 25.

The ligation of intermediates 25 and 20 (Scheme 6) was performed with tetrazole to afford a mixed phosphite triester which was then oxidized with tert-butyl hydroperoxide to the phosphate. Subsequent treatment with dimethylamine led to removal of the cyanoethyl group and formation of the desired phosphodiester dimethylammonium salt $\mathbf{2 6}$ in $68 \%$ yield.

For the final removal of the seventeen $O$-benzyl- and $\mathrm{Z}$ groups the Pearlman catalyst ${ }^{[33]}$ was used with $\mathrm{H}_{2}$ under high pressure conditions in a $\mathrm{THF} / \mathrm{H}_{2} \mathrm{O}(2: 1)$ solvent mixture. Target molecule $\mathbf{1}$ a was isolated in highly pure form after hydrophobic interaction chromatography with an ammonium acetate $/ n$ propanol gradient. ${ }^{[34]}$ The charge deconvoluted ESI FT ICR (electron spray ionization Fourier transformation ion cyclotron resonance) mass spectrum obtained using the negative ion mode revealed many molecular mass peaks that were in perfect agreement with the mass calculated for $\mathbf{1 a}$ $\left(\mathrm{C}_{96} \mathrm{H}_{179} \mathrm{O}_{49} \mathrm{~N}_{8} \mathrm{P}_{3}\right.$; calcd: $M=2321.0974$; found 2321.1038). For NMR spectroscopy a solvent mixture of $\left[\mathrm{D}_{4}\right] \mathrm{MeOH}$ and $\mathrm{D}_{2} \mathrm{O}(7: 3,310 \mathrm{~K})$ provided the best spectral resolution. High coupling constants $\left({ }^{3} J_{1,2} \approx 8 \mathrm{~Hz}\right)$ of the anomeric $\mathrm{H} 1$ resonances for residues $\mathbf{B}, \mathbf{C}, \mathbf{E}$, and $\mathbf{H}$ revealed $\beta$ linkages, whereas ${ }^{3} J_{1,2} \approx 3.7 \mathrm{~Hz}$ for sugars $\mathbf{A}, \mathbf{F}$, and $\mathbf{G}$ indicated $\alpha$-anomeric linkages (Table 1). In the ROESY experiment all connectivities between the anomeric and protons next to those of the adjacent sugar residues $(\mathrm{H}-$ $3^{\mathrm{a}, \mathrm{b}, \mathrm{e}, \mathrm{g}}$ and $\mathrm{H}-4^{\mathrm{f}}$ ) could be unambiguously assigned, thereby allowing the determination of the correct linkage pattern of 1a. In addition, the NMR data are in good agreement with those reported for the natural material, ${ }^{[4,13]}$ thereby additionally confirming the previous structural assignments.

The induction of innate immune response by synthetic $\mathbf{1 a}$ was tested in human peripheral blood cells using a wholeblood assay and isolated human mononuclear cells (Figure 1) ${ }^{[35,36]}$ Both tests revealed that $\mathbf{1 a}$ stimulated the release of pro-inflammatory cytokines such as IL-8, but it was much weaker as compared to lipopolysaccharide (LPS) and synthetic lipopeptide $\mathrm{Pam}_{3} \mathrm{CSK}_{4}$. However, contrary to pre- 


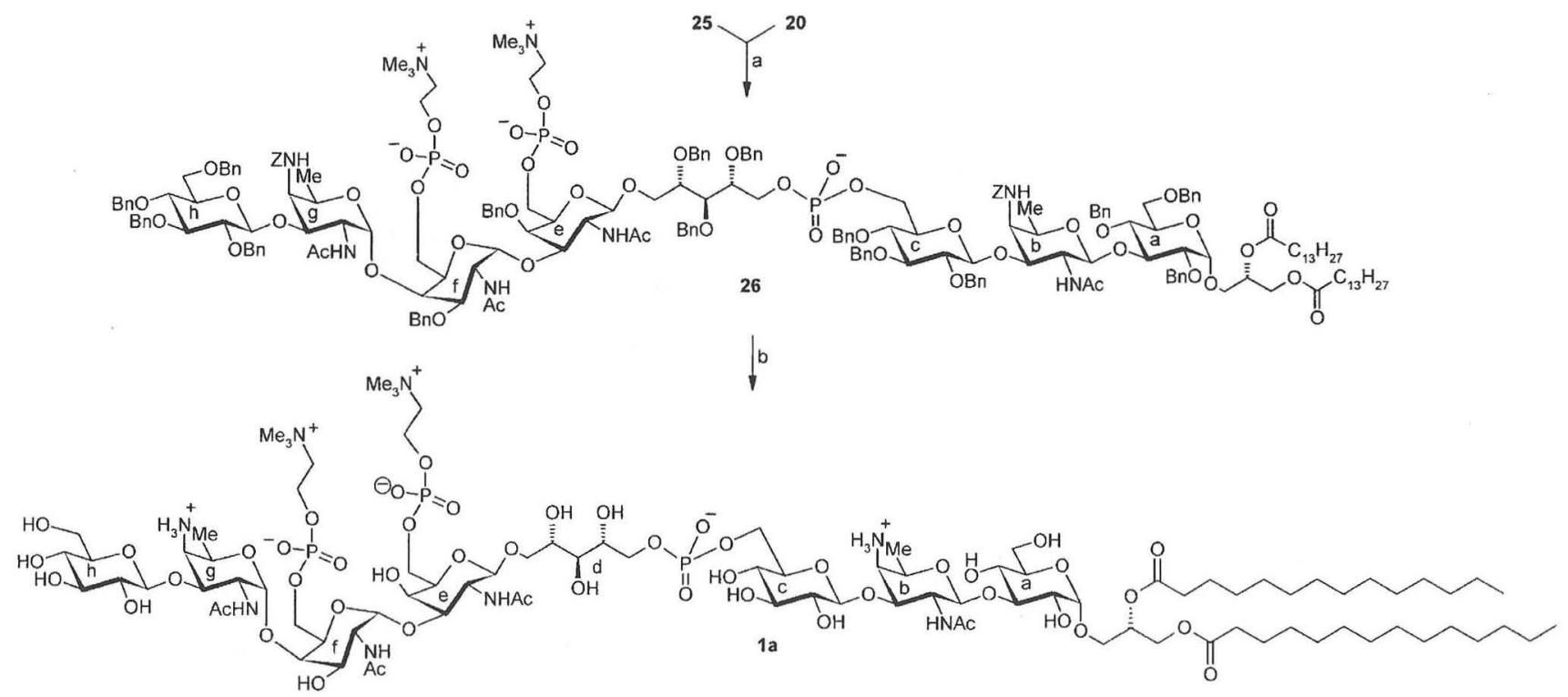

Scheme 6. Synthesis of the target molecule. Reagents and conditions: a) Tetrazole, MeCN, M.S. (3 A) ; then $t \mathrm{BuO}_{2} \mathrm{H} ; \mathrm{Me}_{2} \mathrm{NH}$, EtOH $(68 \%)$; b) $\mathrm{Pd}(\mathrm{OH})_{2} / \mathrm{C}$, $\mathrm{H}_{2}, 40 \mathrm{~atm}, \mathrm{THF} / \mathrm{H}_{2} \mathrm{O}(2: 1)$; then $\mathrm{HIC}$ for purification. $\mathrm{HIC}=$ hydrophobic interaction chromatography, M.S. = molecular sieves.

\begin{tabular}{|c|c|c|c|c|c|}
\hline \multicolumn{2}{|l|}{${ }^{1} \mathrm{H}$} & \multicolumn{2}{|l|}{${ }^{13} \mathrm{C}$} & \multicolumn{2}{|l|}{${ }^{31} \mathrm{p}$} \\
\hline Position ${ }^{[b]}$ & Shift $[\mathrm{ppm}]^{[\mathrm{c}]}$ & Position $^{[d]}$ & Shift [ppm] & Position $^{[e]}$ & Shift [ppm] \\
\hline 1a & $4.78(3.7)$ & $1 a$ & 102.2 & & \\
\hline $1 \mathrm{~b}$ & $4.71(8.5)$ & 16 & 104.4 & & \\
\hline 1c & $4.66(7.8)$ & $1 c$ & 106.8 & $6 c$ & 1.56 \\
\hline 1d & $3.98 / 4.07$ & $1 d$ & 67.8 & $1 d$ & 1.56 \\
\hline le & $4.69(8.3)$ & 1e & 106.9 & $6 e$ & $-0.25^{[f]}$ \\
\hline if & $5.19(3.8)$ & If & 96.2 & $6 f$ & $-0.67^{[f]}$ \\
\hline $\lg$ & $5.08(3.8)$ & $1 \mathrm{~g}$ & 102.1 & & \\
\hline $1 \mathrm{~h}$ & $4.66(7.8)$ & $1 \mathrm{~h}$ & 104.3 & & \\
\hline
\end{tabular}

[a] ${ }^{1} \mathrm{H}(600.3 \mathrm{MHz}),{ }^{13} \mathrm{C}(90.6 \mathrm{MHz}),{ }^{31} \mathrm{P}(243.1 \mathrm{MHz})$. NMR spectra were recorded in $\left[\mathrm{D}_{4}\right] \mathrm{MeOH} / \mathrm{D}_{2} \mathrm{O}=7: 3(\mathrm{v} / \mathrm{v})$ at $310 \mathrm{~K}\left(\mathrm{TSP} \delta_{\mathrm{H}}, \delta_{\mathrm{C}}=0.00 \mathrm{ppm}\right.$; $\delta_{\mathrm{p}}=0.00 \mathrm{ppm}$, external $85 \%$ aq. $\mathrm{H}_{3} \mathrm{PO}_{4}$ ). [b] The number indicates the carbon atom to which the proton is attached and the letter represents the specific pyran ring. [c] Values in brackets indicate $3_{1,2}$ coupling constants $(\mathrm{Hz})$ of the anomeric protons. [d] The number represents the carbon atom and the letter represents the specific pyran ring. [e] The number represents the carbon atom to which the OP group is attached and the letter represents the specific pyran ring. [f] Assignment may have to be interchanged. For the complete ${ }^{1} \mathrm{H}$ and ${ }^{13} \mathrm{C}$ NMR data see the Supporting Information.

vious postulations, ${ }^{[6]}$ TLR-2 is not the signaling receptor for synthetic LTA $1 a^{[37]}$

In conclusion, LTA $\mathbf{1 a}$ is structurally a highly complex glycophospholipid that was successfully synthesized for the first time in 88 steps from the sugar precursors. The nine building blocks could be either stereoselectively glycosidically linked or linked by phosphodiester formation, respectively, in a convergent manner. Modification of these building blocks will permit a modular synthesis of S. pneumoniae LTAs of other strains. The structure of $\mathbf{1 a}$ was determined and the previous structural assignment of the natural material confirmed. Compound $\mathbf{1}$ a exhibits immunological activity result-
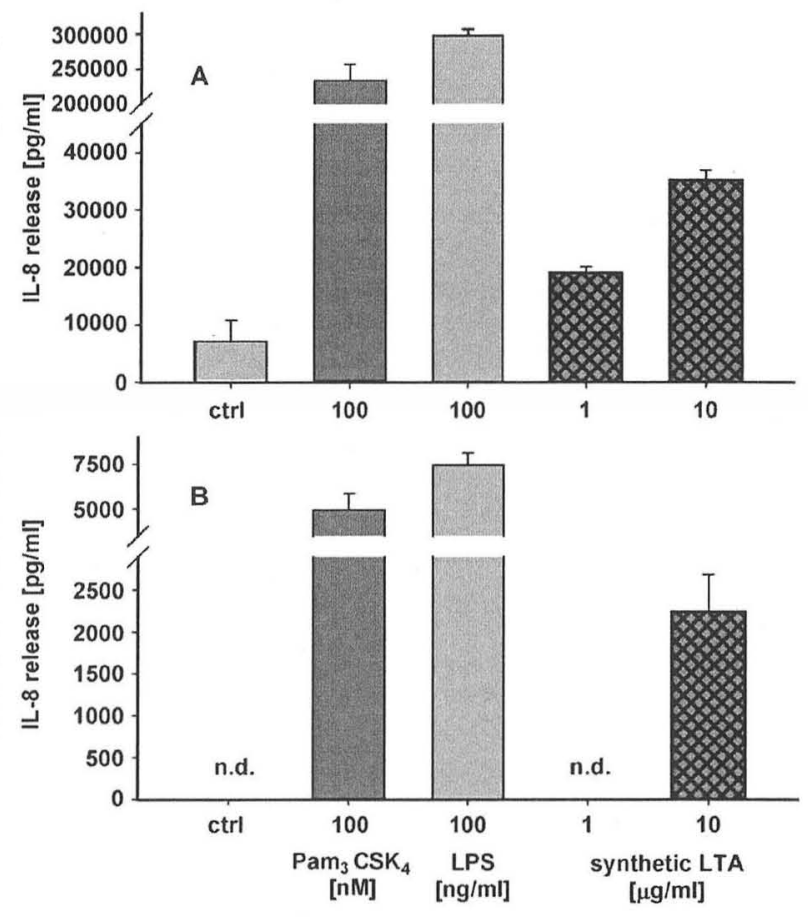

Figure 1. Induction of IL-8 release by synthetic LTA from S. pneumoniae. Human MNC (A) or human whole-blood cells (B) were stimulated for $16 \mathrm{~h}$ with synthetic LTA from S. pneumoniae at $1 \mu \mathrm{g} \mathrm{m}^{-1}$ and $10 \mu \mathrm{g} \mathrm{mL}^{-1}$. Pam $_{3} \mathrm{CSK}_{4}(100 \mathrm{nM})$ and LPS $\left(100 \mathrm{ng} \mathrm{mL}^{-1}\right)$ were used as control stimulus. The IL-8 release in the culture supernatant was determined by ELISA. Each value represents the mean of triplicate cultures $\pm S D$, n.d. $=$ not detectable amounts. For details, see the Supporting Information.

ing in cytokine release, but so far it proceeds through an unknown mechanism, as TLR-2 and TLR-4 are not the signaling receptors for synthetic pneumococcal LTA ${ }^{[36]}$ Addi- 
tional studies with the synthetic material should result in a better understanding of the immune response, which in turn might lead to new treatment opportunities against S. pneumoniae and Gram-positive bacterial infections in general.

Received: November 2, 2009

Revised: January 14, 2010

Published online: March 9, 2010

Keywords: cytokines - glycolipids · glycosylation .

Gram-positive bacteria $\cdot$ total synthesis

[1] K. M. Zangwill, C. M. Vadheim, A. M. Vannier, L. S. Hemenway, P. D. Greenberg, J. I. Ward, J. Infect. Dis. 1996, 174, 752 759

[2] M. J. Jedrzejas, Microbiol. Mol. Biol. Rev. 2001, 65, 187-207.

[3] F. D. Lowy, N. Engl. J. Med. 1998, 339, 520-532.

[4] W. Fischer, T. Behr, R. Hartmann, J. Peter-Katalinic, H. Egge, Eur. J. Biochem. 1993, 215, 851-857; J. W. Greenberg, W. Fischer, K. A. Jonier, Infect. Immun. 1996, 64, 3318-3325; W. Fischer, Microb. Drug Resist. 1997, 3, 309-325.

[5] This division into lipid anchor and repeating unit was introduced by Fischer et al., ref. [4]. Recently a different division between lipid anchor and repeating unit was proposed: H. S. Seo, R. T. Cartree, D. G. Pritchard, M. H. Nahm, J. Bacteriol. 2008, 190, 2379-2387.

[6] K. Hoebe, P. Georgel, S. Rutschmann, X. Du, S. Mudd, K. Crozat, S. Sovath, L. Shamel, T. Hartung, U. Zähringer, B. Beutle, Nature 2005, 433, 523-527; A. Stadelmaier, S. Morath, T. Hartung, R. R. Schmidt, Angew. Chem. 2003, 115, 945-949; Angew. Chem. Int. Ed. 2003, 42, 916-920; S. H. Han, J. K. Kim, M. Martin, S. M. Michalek, M. H. Nahm, Infect. Immun. 2003, $71,5541-5548$.

[7] N. W. Schröder, S. Morath, C. Alexander, L. Hamann, T. Hartung, U. Zähringer, U. B. Göbel, J. R. Weber, R. R. Schumann, J. Biol. Chem. 2003, 278, 15587-15594.

[8] U. Zähringer, B. Lindner, S. Inamura, H. Heine, C. Alexander, Immunobiology 2008, 213, 205-224.

[9] K. Tawaratsumida, M. Furuyashiki, Y. Fujimoto, K. Fukase, Y. Suda, M. Hashimoto, J. Biol. Chem. 2009, 284, 9147-9152; M. Hashimoto, M. Furuyashiki, Y. Suda, J. Immunol. 2007, 178, 2610-2611; M. Hashimoto, K. Tawaratsumida, H. Kariya, A. Kiyohara, Y. Suda, F. Kirikae, T. Kirikae, F. Götz, J. Immunol. 2006, 177, 3162-3169.

[10] S. von Aulock, T. Hartung, C. Hermann, J. Immunol. 2007, 178, 2610.

[11] K. Kurokawa, H. Lee, K.-B. Roh, M. Asanuma, Y. S. Kim, H. Nakayama, A. Shiatsuchi, Y. Choi, O. Takenchi, H. J. Kang, N. Dohmae, Y. Nakanishi, S. Akira, K. Sekimizu, B. L. Lee, J. Biol. Chem. 2009, 284, 8406-8411.

[12] S. Vialle, P. Sepulcri, J. Dubayle, P. Talaga, Carbohydr. Res. 2005, 340, $91-96$.

[13] C. Draing, M. Pfitzenmaier, S. Zummo, G. Mancuso, A. Geyer, T. Hartung, S. von Aulock, J. Biol. Chem. 2006, 281, 3384933859 .
[14] M. Kovacs, A. Halfmann, I. Fedtke, M. Heintz, A. Peschel. W. Vollmer, R. Hakenbeck, R. Bruckner, J. Bacteriol. 2006, 188 , 5797-5805.

[15] R. R. Schmidt, Angew. Chem. 1986, 98, 213-236; Angew. Chem. Int. Ed. Engl. 1986, 25, 212-235; R. R. Schmidt, W. Kinzy, $A d v$ Carbohydr. Chem. Biochem. 1994, 50, 21-123; X. Zhu, R. R. Schmidt, Angew. Chem. 2009, 121, 1932-1967; Angew. Chem. Int. Ed. 2009, 48, 1900-1934.

[16] P. Smid, M. de Zwart, W. P. A. Jörning, G. A. van der Marel J. H. van Boom, J. Carbohydr. Chem. 1993, 12, 1073-1090; H. Liang, T. B. Grindley, J. Carbohydr. Chem. 2004, 23, 71 -82; L. J. van den Bos, T. J. Boltje, T. Provoest, J. Mazurek, H. S. Overkleeft, G. A. van der Marel, Tetrahedron Lett. 2007, 48, 2967 2970, and references therein.

[17] C. M. Pedersen, I. Figueroa-Perez, J. Boruwa, B. Lindner, U. Zähringer, R. R. Schmidt, manuscript in preparation.

[18] R. Yan, F. Wang, Y. Wu, L. Zhang, X. Ye, Tetrahedron Lett. 2005, 46, 8991-8995.

[19] H. Qui, T. B. Grindley, Can. J. Chem. 1999, 77, 481-494.

[20] S. D. Markad, R. R. Schmidt, Eur. J. Org. Chem. 2009, 5002 5011; A. K. Sarkar, K. S. Rostand, R. K. Jain, K. L. Matta, J. D. Esko, J. Biol. Chem. 1997, 272, 25608.

[21] R. R. Schmidt, E. Rücker, Tetrahedron Lett. 1980, 21, 1421 1424; R. R. Schmidt, M. Behrendt, A. Toepfer, Synlett 1990 694-697.

[22] A. H. Andreotti, D. Kahne, J. Am. Chem. Soc. 1993, 115, 3352 3353.

[23] J. A. Ragan, K. Cooper, Bioorg. Med. Chem. Lett. 1994, 4, 2563 2566.

[24] P. A. Gent, R. Gigg, J. Chem. Soc. Perkin Trans. 1 1974, 1835 1839.

[25] This compound is also commercially available.

[26] J. D. Codée, L. H. Hossain, P. H. Seeberger, Org. Lett. 2005, 7 , $3251-3254$.

[27] M. Honda, H. Morita, I. Nagakura, J. Org. Chem. 1997, 62, 8932.

[28] W. Dullenkopf, J. C. Castro-Palomino, L. Manzoni, R. R. Schmidt, Carbohydr. Res. 1996, 296, 135-147.

[29] W. Bannwarth, A. Trzeciak, Helv. Chim. Acta 1987, 70, 175-186; B. Kratzer. Dissertation, Universität Konstanz, 1994.

[30] O. Kanie, S. C. Crawley, M. M. Palcic, O. Hindsgaul, Carbohydr. Res. 1993, 243, 139-164.

[31] N. Hada, Y. Shida, H. Shimamura, Y. Sonoda, T. Kasahara, M. Sugita, T. Takeda, Carbohydr. Res. 2008, 343, 2221-2228.

[32] Y.-J Hu, R. Dominique, S. K. Das, R. Roy, Can. J. Chem. 2000, $78,838-845$

[33] Fieser \& Fieser, Reagents for Organic Synthesis, Vol. 1, Wiley, 1967 , p. 782.

[34] T. Behr, W. Fischer, J. Peter-Katalinic, H. Egge, Eur. J. Biochem. 1992, 207, 1063-1075.

[35] K. Farhat, S. Riekenberg, H. Heine, J. Debarry, R. Lang, J. Mages, U. Buwitt-Beckmann, K. Röschmann, G. Jung, K. H. Wiesmüller, A. J. Ulmer, J. Leukocyte Biol. 2008, 83, 692-701.

[36] O. Umland, H. Heine, M. Miehe, K. Marienfeld, K. H. Staubach, A. J. Ulmer, J. Leukocyte Biol. 2004, 75, 671-679.

[37] Additional results will be reported in due course. 